\title{
Social approaching to create the tolerance in indonesia
}

\author{
Dermawan Waruwu ${ }^{1}$, Made Nyandra ${ }^{2}$, Ni Made Diana Erfiani ${ }^{3}$, R Tri Priyono Budi Santoso ${ }^{4}$, \\ Suardin Gaurifa ${ }^{5}$, \\ \{dermawanwaruwu@undhirabali.ac.id', madenyandra@undhirabali.ac.id², \\ dianaerfiani@undhirabali.ac.id ${ }^{3}$, budisantoso@undhirabali.ac.id ${ }^{4}$, suardingaurifa@sttpk- \\ medan.ac.id $\left.{ }^{5}\right\}$
}

Program Studi Psikologi Universitas Dhyana Pura ${ }^{1}$, Program Studi Kesehatan Masyarakat, Universitas Dhyana Pura ${ }^{2}$, Program Studi Sastra Inggris, Universitas Dhyana Pura ${ }^{3}$, Program studi Manajemen, Universitas Dhyana Pura ${ }^{4}$, Sekolah Tinggi Teologi Pelita Kebenaran ${ }^{5}$

\begin{abstract}
The Creator designs for human life. The social foundation which sticks to everyone is dependable to each other. No one is able to go through his life well without others. However, the world civilisation is kept on improving alongside with the increasing population thus creating complex plurarity. Not only the plurarity in personality but also in all lines which create unstopable plurarity in religion, beliefs, customs and cultures, languages and others. The situation becomes a positive area and also becomes an exclusive challenge for the ongoing community society in the county. Recently, the trending hot social issues in Indonesia are miserable. Intolerance has happened on several areas become a serious task for the security department to encounter and overcome. These situations have urged the needof social community perspective to act as the balancing and preventing indicators for the intolerance acts occured in Indonesia.
\end{abstract}

Keywords: social approaching, tolerance

\section{Introduction}

Development of the word is unable to withstand the changing movement on the social aspects. The high acceleration of the technology era contributes the implication of social behaviours. Human life orientation has changed as the result of the fast improving of the neighbouring. Thus, sociology perspective among human shows negative attitudes because of the domination of materialistic thinking in general. Living competition has become the main movement which is able to decrease the relationship among each other. Not only the income aspect and living amenities struggling but also the fames, religions, ethnics, tribes and beliefs have given the contribution too. The shiftings are hardly to avoid the social conflicts in the the midnist of the society. In the end these conflicts may bear the intolerance behaviours and attitudes as the strategy to protect the succeed life in community. The intolerance pressures are gaining the threats to those want to create own superiority for both the individuals and groups. Indonesia is one of the open free-will countries, will be a great opportunity for the outer parties to come into the country. There is no exception of radicalism which is the product of other countries which enters and tries to build the influence in the country. The implication is a growing misunderstanding among each other.

Moreover, there are harsh ways in the socializing of ideology being used to win over the followers of the ideology of radicalism. A sound of a significant growing of intolerance acts 
occured. According to the data revealed by SETARA Institute, there were 109 cases of discrimination of intolerance, hatred statements on 20 provinces in Indonesia in the year 2018, showing an increasing from 80 cases in the year 2017.

Intolerance is due to the radicalism understanding which entered Indonesia in the form of ideology with a close related to belief in religion. Recently Indonesia has a problem in the part of developing radicalism issues as the results of the global issues that has been spreading to all aspects such Al-Qaeda and ISIS. Those groups as the form of the oppression to global radicalism towards the unfair actions of the world happenings. These matters are linked to the actions 'sliding' by the world's leaders towards Palestine, the huge economic gaps in Islamic countries and also the West culture expansion that being issued to demolish Islam values such as hedonism and materialism. Moreover, the appearance of radicalism is one of the contribution of the changing order of social politics, as the implication of outside parties have brought in the country the new ideology, the harsh ideology and intolerance acknowledge. (Ahmad asrori, 2015)

\section{Research method}

The research is based on the qualitative descriptive. The gathered data by collecting literatures, observations from the development of intolerance issues in Indonesia from various medias. Indonesia is a large archipelago country in the world located in South east Asia, in between Asia and Australia continents, on \{lintang dan bujur\}together in the 2 oceans, Pacific and Indian alongside located on the equator. Indonesia has 250.580 .739 people (estimation on July 2017) with its majority Islam religion (around 87.2\%). With 260 million people has put Indonesia into the 4th largest population in the world (around 227 million people are Mosleem). Below table shows the percentage pof population according to the religion. \{ tabel dri format Indo\}. Population according to the local tribes are as follows \{ambil data dri format indo\}

Tolerance is the essential need to support the sustainable living society. According to the sociology meaning, tolerance has about 5 possibility foundations, such as openness to diversity fo a peaceful life, respecting the developing difference on the society without being forced to be unity, admitting others rights, expressing of acceptance others by real actions such as to listen, to make friends, to give support on differences. (Michael Walzer 1997)

Tolerance is a foundation on respecting and symphatizing others. (Abdurrahman Wahid, 2011). One of the approaching to crerate tolerance in Indonesia is via social approaching which is the fittest for the diversity communities. There are 2 ways of approaching perspective in order to build a social solidarity among the communities, social system and culture system.

Perspective of social system via inter-group relation is the relationship among the members from the various kind of groups. The more intensive the relationship among the groups, the higher the level of integrity among them. This inter-group relation can also neutralize the group conflicts as there are no single loyality among the members of each group, but they have twin sharing loyality according to the groups they have entered. Therefore, this reduces the 
worriedness of fanaticism occurance, the neutralizing of primordial sentiments as there are twinsharing loyality possess by the group members.

The importance of social approacing in the form of culture due to the possibility of people plurarity to be united., if there is general value acceptance in the community. The values are from the community culture which is having multi ethnics as the measurement of the right attitudes. The most important thing to be crystalized is there is recognition and acceptance on differences. Within those will bear a positive impact in relation with religion aspect as well in the end the democracy and tolerance should have a close connection in both the society of politics and civil.

\section{Conclusion}

Social development is a part of history development in community particularly in Indonesia. the true contribution has given significant problems which occured in the society. Moreover, Indonesia is one of the biggest nation in the world based on the width of area, huge population and also the diverse plurality, gives both positive and negative contributions. The real negative aspects are becoming the strong issues in intolerance acts. Shifting social life is due to the economics and politics factors which contribute to negative support for the growing development of intolerance in the country. Lastly, the need of tolerance is particularly the main point in community living. The attempts to create the tolerance may reach by the social approaching. The reason is the country as a diversity in tribes, languages, religions and cultures thus the social values are the best bait to be the stimulus for tolerance creating in Indonesia. development of friendship, rspecting each other with the point of social values and community cultures are a must movement to be carried forward. Within the approaching of relationship among cummunities will be a blueprint of social approaching to minimalize the intolerance acts occurance.

\section{Reference}

[1] Michael Walzer, On toleration, (New Heaven\& London: Yale University Press, 1997), 10.

[2] KH. Abdurrahman Wahid \& Daisaku Ikeda, Dialog peradaban untuk Toleransi dan Perdamaian, (Jakarta: Gramedia Pustaka Utama, 2011), 247.

[3] KH. Ahmad Asrori, Radikalisme di Indonesia antara Historisitas dan Antropisitas Jurnal Studi Agama dan Pemikiran Islam,Vol.9 Nomor 2, Desember 2015, 254-255.

[4] https://www.ucanews.com/news/religious-intolerance-on-the-rise-inindonesia/83131, diakses tanggal 8 Maret 2019.

[5] https://ilmupengetahuanumum.com/profil-negara-indonesia/, diakses tanggal 8 Maret 2019.

[6] Dibyorini, MC.Candra Rusmala. 2005. "Solidaritas Sosial dalam kemajemukan Masyarakat Indonesia", Artikel dalam jurnal Ilmu Sosial Alternatif, Volume VI, 
Nomor 12, Desember 2005, Yogyakarta: Sekolah Tinggi Pembangunan Masyarakat Desa "APMD".

[7] Misrawi, Zuhairi. 2008. “Toleransi Sebagai Kuasa Nilai”, Kompas 24 Mei. 